\title{
Türkiye’de Taşınmaz Değerleme Alanında Yapılan Lisansüstü Tezlerinin İçerik Analizi
}

\author{
${ }^{* 1}$ Nuri Erdem \\ Osmaniye Korkut Ata Üniversitesi, Mühendislik Fakültesi, Harita Mühendisliği Bölümü, Osmaniye, Türkiye, \\ nurierdem@osmaniye.edu.tr
}

Geliș Tarihi: 2017-08-04 Kabul Tarihi: 2018-01-30

\section{$\ddot{\mathbf{O} z}$}

\begin{abstract}
Akademik alanda bilimsel çalışmaların taranması ile ilgili olarak, yapılmış lisansüstü tezlerini analiz eden birçok araştırmaya rastlamak mümkündür. Ancak, taşınmaz değerlemesi alanında bugüne kadar böyle bir çalışma yapılmamıştır. Bu çalışmada, taşınmaz (gayrimenkul) değerlemesi alanında yapılan lisansüstü tezlerinin genel bir incelemesi yapılmıştır. Bu amaçla 1990-2017 yılları içerisinde Türkiye'de taşınmaz değerlemesi alanında yapılan lisansüstü tezlerinin genel profili belirlenmeye çalışılmıştır. Öncelikle, Yükseköğretim Kurulu Yayın ve Dokümantasyon Daire Başkanlığı Ulusal Tez Merkezinin açı erişimli olan internet (https://tez.yok.gov.tr/UlusalTezMerkezi/) sitesinden konuyla ilgili tezler indirilmiş, içerik analiz yöntemiyle analiz edilmiştir. Yapılan taramalar sonucu 2017 yılına kadar taşınmaz değerleme alanında tamamlanan 126 adet lisansüstü (108 yüksek lisans ve 18 doktora) tezi değerlendirmeye alınmıştır.
\end{abstract}

Anahtar kelimeler: Taşınmaz değerlemesi, Lisansüstü tez, İçerik analizi.

\section{The Content Analysis on Graduate Theses in the Field of Real Estate Valuation in Turkey}

\author{
*11Nuri Erdem \\ Osmaniye Korkut Ata University, Faculty Of Engineering, Department Of Map Engineering, Osmaniye, Turkey, \\ nurierdem@osmaniye.edu.tr
}

\begin{abstract}
With regard to the screening of scholarly studies in the academic field, it is possible to come across many researches that analyze post-graduate dissertations. However, in the field of real estate valuation has not been carried out such a study until today. In this study, it has been made a general review of postgraduate theses on real estate valuation. For this purpose, it was tried to determine the general profile of postgraduate theses on real estate evaluation between 1990 and 2017 in Turkey. Firstly, related theses were downloaded from internet (https://tez.yok.gov.tr/UlusalTezMerkezi/) which is open access of the National Dissertation Center of the Publication and Documentation Department of the Higher Education Council and analyzed by content analysis method. 126 graduate (108 masters and 18 doctorates) theses completed in real estate valuation area until 2017 have been taken into consideration as a result of the research.
\end{abstract}

Keywords: Real estate valuation, Graduate thesis, Content analysis.

\section{GIRISS}

Taşınmaz (İngilizce: Real Estate); arazi ve üzerindeki binalara bir bütün olarak verilen addır [1]. Taşınamayan tüm arsa, arazi, tarla, bağ, bahçe, ev, bina gibi varlıkların genel adıdır. Taşınmaz yerine sıklıkla gayrimenkul kavramı da kullanılmaktadır. Türk Dil Kurumu (TDK) taşınmaz kavramını, “ev, tarla vb. taşınamayan mülk, gayrimenkul" olarak tanımlamaktadır [2].

Uluslararası Değerleme Standartları Komitesi (UDSK), Uluslararası Değerleme Standartları (UDES)
Kitabında taşınmaz mülkü (gayrimenkul); "arazi ve ăgaçlar, madenler gibi arazinin doğal parçası olan her şeyin yanı sıra binalar ve iyileştirme çalışmaları gibi insanlar tarafindan yapılmış olan her şey" şeklinde tanımlamaktadır [3].

Candaş (2012)'e göre, 17.02.1926 tarih ve 743 sayılı Türk Kanunu Medenisinde "gayrimenkul" kelimesi kullanılmaktayken, 22.11.2001 tarihinde kabul edilen 4721 sayılı yeni Türk Medeni Kanunu'nda "taşınmaz" kelimesi kullanılmaya başlanmıştır. 3194 sayılı İmar Kanunu, 2942 sayılı Kamulaştırma Kanunu, 3402 sayılı Kadastro Kanunu, 2644 Tapu Kanunu ve birçok

*Sorumlu Yazar: Osmaniye Korkut Ata Üniversitesi, Mühendislik Fakültesi, Harita Mühendisliği Bölümü, Osmaniye, Türkiye, nurierdem@osmaniye.edu.tr 
önemli mevzuatta da "taşınmaz" kelimesi kullanılmaktadır. Diğer taraftan, Tapu Kadastro Genel Müdürlüğü'nün sorumluluğundaki Tapu ve Kadastro Modernizasyon Projesi (TKMP)'nin Değerleme Bileşeni "Gayrimenkul Değerleme" olarak adlandırılmış ve "gayrimenkul" kavramı kullanılmıştır. Sermaye Piyasası Kurulu'nun düzenlemekte olduğu sinavin ve sonucunda alınan lisansın başlığı da yine "Gayrimenkul Değerleme Uzmanlığı"'dır [4].

Dünya değerler sisteminin bir aracı olan taşınmaz, sadece ülkemiz için değil tüm dünya halkları için, ekonomik ve sosyal açıdan önemli bir kavramdır. Dünya nüfusunun giderek artması, tarımsal faaliyet alanlarının azalması, köyden kente göç ve bunlara bağlı olarak meydana gelen hızlı kentleşme gibi etkenler, taşınmazların değerini gün geçtikçe daha da arttırmaktadir.

Günümüzde taşınmaz sektörü ve buna bağlı olarak gelişen taşınmaz değerinin belirlenmesi, uluslararası küresel ekonomik ilişkilerin vazgeçilmez bir unsuru olmuştur. Değerleme faaliyetleri, ekonomik sistemde bir bütünün içinde geniş bir yer tutmakta ve farklı amaçlarla kullanılmaktadır. Taşınmaz değerlerinin belirlenmesi işi ve bu değerlerin likidite olarak piyasada işlem görebiliyor olması, sağlıklı bir ekonomik yapının en önemli unsurlarıdır [5].

Genel olarak taşınmaz (gayrimenkul) değerlemesi; "bir taşınmazın, taşınmaz projesinin ya da taşınmaza bağlı hak ve faydaların değerleme günündeki olası değerinin, bağımsız, tarafsız ve objektif ölçütlere dayanarak kestirimi" olarak tanımlanabilir [3], [6]. Ayrıca taşınmaz değerlendirmesi, bir taşınmazın kısmen veya tamamen nitelik ve nicelikler bakımından ifade edilmesidir [7]. Günümüzde taşınmaz değerlemeye; vergilendirme, kamulaştırma, özelleştirme, arazi ve arsa düzenlemeleri, tescile esas işlemler gibi kamusal uygulamaların yanı sıra sermaye piyasası, bankacılık ve sigortacılık gibi özel sektör uygulamalarında da yoğun bir şekilde ihtiyaç duyulmaktadır [8], [9].

Bilimsel bilginin üretilmesi ve paylaşılması başta üniversitelerin olmak üzere tüm eğitim kurumlarının en önemli görevlerinden biridir. $\mathrm{Bu}$ bağlamda üniversiteler, lisansüstü eğitim sürecinde yapılan araştırmalar ile kuruluş amaçlarından birisi olan araştırma yapmak ve yeni teknolojiler üretmek gibi görevlerinin önemli bir bölümünü yerine getirmektedir [10]. Literatürde yüksek lisans ve/veya doktora tezlerini analiz eden birçok bilimsel araştırmaya rastlamak mümkündür. Bu tür çalışmaların sonucunda hem ilgili bilim dalının geçen sürede gösterdiği gelişim belirlenebilir, hem de o konunun kapsama alanı hakkında bilgiler elde edilebilir [10-14].
Nitel araştırmalar alanında kullanılan içerik analizi, çalışmaların özelliklerini sayısal olarak sunmaktadır ve istatistiki sonuçlar vermektedir [10], [15]. Bu yöntem, sosyal bilimlerde yaygın olarak kullanılmasına rağmen, fen bilimleri alanında çok fazla rastlanılmayan bir çalışma türüdür [16]. Alkan (2014)'e göre, “içerik analizinin temel amacı elde edilen verileri açıklamak, veriler arasında ilişki kurmak ve yorumlamaktır. Bu amaçla veriler düzenlenerek kodlanır, temalar belirlenir ve düzenlenir elde edilen bulgular değerlendirilir" [10], [14].

$\mathrm{Bu}$ çalışmada, taşınmaz değerleme alanında gerçekleştirilen lisansüstü tezleri içerik analizi yöntemi kullanılarak sınıflandırılmıştır. Elde edilen sonuçlar değerlendirilmiş, önerilerde bulunulmuştur. Konuyla ilgili lisansüstü tezlerini toplu bir şekilde görmeye imkân veren bu çalışmanın, gelecek çalışmalar açısından önemli bulgular ortaya koyacağ ve bu alanda araştırma yapacak kişilere yol gösterici nitelikte olacağ 1 düşünülmektedir.

\section{ARAŞTIRMANIN YÖNTEMI}

Çalışmaya ilişkin gerekli bilgilere Yükseköğretim Kurulu (YÖK) Yayın ve Dokümantasyon Daire Başkanlığı Ulusal Tez Merkezi'nin açık erişimi olan https://tez.yok.gov.tr/UlusalTezMerkezi/ web sitesi ve Google, Yandex, AltaVista, Bing gibi arama motorlarından ulaşılmıştır. Söz konusu web sitelerindeki arama modülüne öncelikle "gayrimenkul, taşınmaz, konut" kelimeleri ayrı ayrı ve sonrasında "değerleme, değer, değeri" kelimeleri ile birlikte yazılarak ortaya çıkan 400'ü aşkın tezden taşınmaz değerleme konusuyla doğrudan ilgili olan tezler incelemeye alınmıştır. Türkiye'de bu alanda günümüze kadar yapılan toplam 126 adet lisansüstü (108 yüksek lisans, 18 doktora) tezi bulunmuştur.

Ancak, taşınmaz değerleme alanında yoğun faaliyetleri olan Sermaye Piyasası Kurulunun Yeterlilik Etüt Tezleri ile Maliye Bakanlığı Milli Emlak Genel Müdürlüğü Milli Emlak Uzmanlığ Tezleri değerlendirmeye alınmamıştır. Bunun yanında kısıtlı da olsa T.C. Merkez Bankası İstatistik Genel Müdürlüğü tarafından oluşturulan Uzmanlık Yeterlilik Tezleri de inceleme dişında tutulmuştur. Söz konusu bu üç kurum bünyesinde oluşturulan tezler, konu olarak benzer olmasına karşın, esas inceleme alanımız olan YÖK lisansüstü tezlerinden format olarak farklılıklar göstermekte ve içerik analiz yöntemine göre yapılacak olan bu bilimsel çalışmanın esaslarına uymamaktadır.

Tablo 1: Tezlerin Yapıldı̆̆ Enstitüye Göre Dağılımı.

$\begin{array}{lll}\text { Enstitüsü } & \text { Tez Sayısı } & \text { Oranı (\%) } \\ \text { Fen Bilimleri } & 92 & 73.02 \\ \begin{array}{l}\text { Sosyal } \\ \text { Bilimler }\end{array} & 31 & 24.60\end{array}$


Mühendislik

\begin{tabular}{|c|c|c|}
\hline \multirow{2}{*}{\multicolumn{3}{|c|}{$\begin{array}{l}\text { ve Fen } \\
\text { Bilimleri }\end{array}$}} \\
\hline & & \\
\hline $\begin{array}{l}\text { Eğitim } \\
\text { Bilimleri }\end{array}$ & 1 & 0.79 \\
\hline Toplam & 126 & 100.00 \\
\hline
\end{tabular}

Araştırmanın örneklem grubunu; Fen Bilimleri Enstitüsü tarafindan kabul edilen 92 adet,

Sosyal Bilimler Enstitüsüne ait 31 adet, Mühendislik ve Fen Bilimleri Enstitüsünden 2 adet ve Eğitim Bilimleri Enstitüsü bünyesinde tamamlanmış olan 1 adet olmak üzere toplamda 126 adet lisansüstü tezi oluşturmaktadır (Tablo 1). Bu verilerin enstitülere göre \% dağılımları da Tablo 1'de verilmiştir.

\section{ARAŞTIRMANIN BULGULARI}

Ülkemizde taşınmaz değerleme alanında incelenen lisansüstü tezlerin üniversite ve ilgili anabilim dalına göre dağılımı Tablo 2'de verilmiştir. Tabloya göre toplam 35 farklı Devlet veya Vakıf üniversitesinin 38 farklı anabilim dalında taşınmaz değerleme alanında lisansüstü tezleri kabul edilmiştir. Tabloya göre en fazla çalışma 13 adet $(\% 12)$ yüksek lisans tez çalışması ile İTÜ Disiplinler Arası Anabilim dalında yapılmıştır.

Tablo 2: Tezlerin Üniversite ve İlgili Anabilim Dalına Göre Dağılımı.

\begin{tabular}{|c|c|c|c|c|c|c|c|}
\hline \multirow[b]{2}{*}{ Üniversitesi } & \multirow[b]{2}{*}{ Anabilim Dalı } & \multicolumn{2}{|c|}{ Doktora } & \multicolumn{2}{|c|}{ Yüksek Lisans } & \multicolumn{2}{|l|}{ Toplam } \\
\hline & & $\begin{array}{l}\text { Yayını } \\
\text { (Adet) }\end{array}$ & $\begin{array}{l}\text { Oranı } \\
(\%)\end{array}$ & $\begin{array}{l}\text { Yayını } \\
\text { (Adet) }\end{array}$ & $\begin{array}{l}\text { Oranı } \\
(\%)\end{array}$ & $\begin{array}{l}\text { Yayını } \\
\text { (Adet) }\end{array}$ & $\begin{array}{l}\text { Oranı } \\
(\%)\end{array}$ \\
\hline Afyon Kocatepe & Harita & & 0 & 2 & 1.85 & 2 & 1.59 \\
\hline Anadolu & Maliye & 1 & 5.56 & & 0 & 1 & 0.79 \\
\hline Ankara & Peyzaj Mimarlığı & 1 & 5.56 & & & 1 & 0.79 \\
\hline Ankara & Taşınmaz Geliştirme & 1 & 5.56 & 4 & 3.7 & 5 & 3.97 \\
\hline Ankara & Tarım Ekonomisi & & 0 & 2 & 1.85 & 2 & 1.59 \\
\hline Atatürk & Tarım Ekonomisi & & 0 & 1 & 0.93 & 1 & 0.79 \\
\hline Bahçeşehir & İşletme & & 0 & 1 & 0.93 & 1 & 0.79 \\
\hline Bahçeşehir & Kentsel Sistemler ve & & 0 & 3 & 2.78 & 3 & 2.38 \\
\hline Bilkent & Ekonomi & & 0 & 1 & 0.93 & 1 & 0.79 \\
\hline Balıkesir & İnşaat & & 0 & 3 & 2.78 & 3 & 2.38 \\
\hline Boğaziçi & Uluslararası Ticaret Yönetimi & & 0 & 1 & 0.93 & 1 & 0.79 \\
\hline Bülent Ecevit & Harita & & 0 & 1 & 0.93 & 1 & 0.79 \\
\hline Cukurova & İsletme & & 0 & 1 & 0.93 & 1 & 0.79 \\
\hline Çukurova & Ziraat & & 0 & 1 & 0.93 & 1 & 0.79 \\
\hline Çukurova & Uzaktan Algilama ve CBS & & 0 & 1 & 0.93 & 1 & 0.79 \\
\hline Dokuz Eylül & Avrupa Birliği & 1 & 5.56 & & 0 & 1 & 0.79 \\
\hline Dokuz Eylül & İktisat & & 0 & 1 & 0.93 & 1 & 0.79 \\
\hline Dokuz Eylül & Mimarlık & & 0 & 1 & 0.93 & 1 & 0.79 \\
\hline Dokuz Eylül & Bilgisayar & & 0 & 1 & 0.93 & 1 & 0.79 \\
\hline Ege & Tarım Ekonomisi & & 0 & 1 & 0.93 & 1 & 0.79 \\
\hline Ege & İnşaat & & 0 & 2 & 1.85 & 2 & 1.59 \\
\hline Erciyes & Harita & 1 & 5.56 & & 0 & 1 & 0.79 \\
\hline Gazi & Şehir ve Bölge Planlama & & 0 & 1 & 0.93 & 1 & 0.79 \\
\hline Gazi & İktisat & & 0 & 1 & 0.93 & 1 & 0.79 \\
\hline Gazi & İsletme & & 0 & 3 & 2.78 & 3 & 2.38 \\
\hline Gazi & İşletme Eğitimi & & 0 & 1 & 0.93 & 1 & 0.79 \\
\hline Gebze Yüksek & & & & & & & \\
\hline $\begin{array}{l}\text { Teknoloji } \\
\text { Enstitüsü }\end{array}$ & Harita & & 0 & 2 & 1.85 & 2 & 1.59 \\
\hline Gediz & Kentsel Yenileme & & 0 & 1 & 0.93 & 1 & 0.79 \\
\hline Gümüșhane & Harita & & 0 & 1 & 0.93 & 1 & 0.79 \\
\hline İstanbul & Orman & 1 & 5.56 & & 0 & 1 & 0.79 \\
\hline İstanbul & Maliye & & 0 & 1 & 0.93 & 1 & 0.79 \\
\hline İstanbul & İşletme & 1 & 5.56 & & 0 & 1 & 0.79 \\
\hline İstanbul Gelisim & İsletme & & 0 & 1 & 0.93 & 1 & 0.79 \\
\hline İstanbul Bilgi & Uluslararası Finans & & 0 & 1 & 0.93 & 1 & 0.79 \\
\hline İstanbul Kültür & Özel Hukuk & & 0 & 1 & 0.93 & 1 & 0.79 \\
\hline İstanbul Kültür & Hukuk & & 0 & 1 & 0.93 & 1 & 0.79 \\
\hline İstanbul Kültür & İnşaat & & 0 & 1 & 0.93 & 1 & 0.79 \\
\hline
\end{tabular}




\begin{tabular}{|c|c|c|c|c|c|c|c|}
\hline İTÜ & Geomatik & 1 & 5.56 & 6 & 5.56 & 7 & 5.56 \\
\hline İTÜ & Şehir ve Bölge Planlama & & 0 & 1 & 0.93 & 1 & 0.79 \\
\hline İTÜ & Disiplinler Aras1 & & 0 & 13 & 12 & 13 & 10.3 \\
\hline İTÜ & Gayrimenkul Geliștirme & & 0 & 5 & 4.63 & 5 & 3.97 \\
\hline İTÜ & İnşaat & & 0 & 2 & 1.85 & 2 & 1.59 \\
\hline İTÜ & Bilişim Uygulamaları & & 0 & 2 & 1.85 & 2 & 1.59 \\
\hline K. Mehmet Bey & İktisat & & 0 & 1 & 0.93 & 1 & 0.79 \\
\hline Kocaeli & $\begin{array}{l}\text { Siyaset Bilimi ve Kamu } \\
\text { Yönetimi }\end{array}$ & & 0 & 1 & 0.93 & 1 & 0.79 \\
\hline KTÜ & Harita & 3 & 16.7 & 5 & 4.63 & 8 & 6.35 \\
\hline Marmara & Sermaye Piyasası ve Borsa & & 0 & 1 & 0.93 & 1 & 0.79 \\
\hline Marmara & Ekonometri & & 0 & 1 & 0.93 & 1 & 0.79 \\
\hline Marmara & İşletme & 1 & 5.56 & 1 & 0.93 & 2 & 1.59 \\
\hline Mersin & İşletme & & 0 & 1 & 0.93 & 1 & 0.79 \\
\hline Mimar Sinan & Yap1 & & 0 & 1 & 0.93 & 1 & 0.79 \\
\hline ODTÜ & Mimarlık & & 0 & 1 & 0.93 & 1 & 0.79 \\
\hline ODTÜ & İktisat & & 0 & 1 & 0.93 & 1 & 0.79 \\
\hline ODTÜ & Şehir ve Bölge Planlama & & 0 & 1 & 0.93 & 1 & 0.79 \\
\hline ODTÜ & $\begin{array}{l}\text { Jeodezi ve Coğrafi Bilgi } \\
\text { Teknolojileri }\end{array}$ & 1 & 5.56 & & 0 & 1 & 0.79 \\
\hline Ondokuz Mayıs & Harita & & 0 & 3 & 2.78 & 3 & 2.38 \\
\hline Pamukkale & İşletme & & 0 & 1 & 0.93 & 1 & 0.79 \\
\hline Sakarya & İşletme & & 0 & 1 & 0.93 & 1 & 0.79 \\
\hline Selçuk & Harita & 1 & 5.56 & 4 & 3.7 & 5 & 3.97 \\
\hline Selçuk & Kamu Hukuku & & 0 & 1 & 0.93 & 1 & 0.79 \\
\hline Selçuk & İktisat & 1 & 5.56 & & 0 & 1 & 0.79 \\
\hline Selçuk & $\begin{array}{ll}\text { Elektronik } & \text { Bilgisayar } \\
\text { Sistemleri Eğitimi } & \end{array}$ & & 0 & 1 & 0.93 & 1 & 0.79 \\
\hline Tekirdağ & Tarım Ekonomisi & & 0 & 1 & 0.93 & 1 & 0.79 \\
\hline YTÜ & Şehircilik ve Bölge Planlama & & 0 & 2 & 1.85 & 2 & 1.59 \\
\hline YTÜ & Harita & 2 & 11.1 & 6 & 5.56 & 8 & 6.35 \\
\hline YTÜ & Mimarlık & 1 & 5.56 & & 0 & 1 & 0.79 \\
\hline Toplam & & 18 & 100 & 108 & 100 & 126 & 100 \\
\hline
\end{tabular}

Anabilim dallarıyla ilgili dağılım incelendiğinde çok farklı anabilim dallarında konuyla ilgili çalışmalar yapıldığı görülmektedir (Tablo 3). En fazla çalışma 26 adet tez (\%20.6) ile Jeodezi ve Fotogrametri anabilim dalında kabul edilmiştir. İkinci sırada her biri 12 adet tez (\%9.52) ile Disiplinler Arası anabilim dalı ve İşletme anabilim dalı gelmektedir. Üçüncü sırada ise 10 adet tez (\%7.94) ile Harita Mühendisliği anabilim dalı yer almaktadır. Bunları 8 adet (\%6.35) tez ile İnşaat Mühendisliği anabilim dalı takip etmektedir. Ayrica 5'er adet tez (\%3.97) ile Tarım Ekonomisi, Gayrimenkul Geliştirme, İktisat, Tarım Ekonomisi ve

Taşınmaz Geliştirme anabilim dallarında da taşınmaz değerleme konusunda tezler kabul edilmiştir. Geriye kalan diğer anabilim dallarında $1(\% 0.79)$ ile 3 (\%2.38) arasında değişen sayılarda yüksek lisans tezleri yayınlanmıştır. Taşınmaz değerleme alanı, taşınmazların gün geçtikçe artan sosyal ve ekonomik öneminden dolayı disiplinler arası çalı̧̧ma konusu olmuştur. Bunun bir sonucu olarak, ülkemizdeki taşınmazlar dünyasıyla ilgili akademisyenlerin pek çoğu taşınmaz değerleme alanında çalışma yapmayı tercih etmiştir (Tablo 3).

Tablo 3: Anabilim Dalına Göre Tez Sayılarının Dağılımı.

$\begin{array}{llll}\begin{array}{l}\text { Sira } \\ \text { No }\end{array} & \text { Anabilim Dalı } & \begin{array}{l}\text { Tez } \\ \text { Sayısı }\end{array} & \begin{array}{l}\text { Oran } \\ \text { \% }\end{array} \\ 1 & \text { Avrupa Birliği } & 1 & 0.79 \\ 2 & \text { Bilgisayar Müh. } & 1 & 0.79 \\ 3 & \text { Bilişim Uygulamaları } & 1 & 0.79 \\ 4 & \text { Disiplinler Arası } & 12 & 9.52 \\ 5 & \text { Ekonometri } & 1 & 0.79 \\ 6 & \text { Ekonomi Bölümü } & 1 & 0.79 \\ 7 & \text { Elektronik ve Bilgisayar } & 1 & 0.79\end{array}$

\begin{tabular}{|c|c|c|}
\hline 8 & Gayrimenkul Geliştirme & 5 \\
\hline 9 & Geomatik Mühendisliği & 1 \\
\hline 10 & Harita Mühendisliği & 10 \\
\hline 11 & Hukuk & 1 \\
\hline 12 & İktisat & 5 \\
\hline 13 & İnşaat Mühendisliği & 8 \\
\hline 14 & İşletme & 12 \\
\hline 15 & İşletme Eğitimi & 1 \\
\hline 16 & $\begin{array}{l}\text { Jeodezi ve Coğrafi Bilgi } \\
\text { Teknolojileri }\end{array}$ & 1 \\
\hline 17 & Jeodezi ve Fotogrametri & 26 \\
\hline 18 & Kamu Hukuku & 1 \\
\hline
\end{tabular}




\begin{tabular}{|c|c|c|c|}
\hline 19 & Kentsel Sistemler ve & 3 & 2.38 \\
\hline & Kentsel Yenileme & 1 & $0.7 c$ \\
\hline & Maliye & 2 & 1.5 \\
\hline & $\begin{array}{l}\text { Medeni Usul ve İcra - } \\
\text { İflas Hukuku }\end{array}$ & 1 & 0.79 \\
\hline & Mimarlık & 3 & 2.38 \\
\hline & Muhasebe - Finansman & 1 & 0.79 \\
\hline & Orman Mühendisliği & 1 & 0.79 \\
\hline & Özel Hukuk & 2 & $1.5 \mathrm{C}$ \\
\hline & Peyzaj Mimarlı̆̆ 1 & 1 & 0.79 \\
\hline & $\begin{array}{l}\text { Sermaye Piyasası ve } \\
\text { Borsa }\end{array}$ & 1 & 0.79 \\
\hline & $\begin{array}{l}\text { Siyaset Bilimi ve Kamu } \\
\text { Yönetimi }\end{array}$ & 1 & 0.79 \\
\hline & Şehir ve Bölge Planlama & 3 & 2.38 \\
\hline & $\begin{array}{l}\text { Şehircilik ve Bölge } \\
\text { Planlama }\end{array}$ & 2 & 1.59 \\
\hline & Tarım Ekonomisi & 5 & 97 \\
\hline & Taşınmaz Geliştirme & 5 & 3.97 \\
\hline & $\begin{array}{ll}\text { Uluslararası } & \text { Ticaret } \\
\text { Yönetimi } & \end{array}$ & 1 & 0.79 \\
\hline & Uluslararası Finans & 1 & 0.79 \\
\hline & $\begin{array}{l}\text { Uzaktan Algilama ve } \\
\text { Coğrafi Bilgi Sistemleri }\end{array}$ & 1 & 0.1 \\
\hline & Yap1 & 1 & 0.7 \\
\hline & Ziraat & 1 & 0.7 \\
\hline & & 126 & 10 \\
\hline
\end{tabular}

Tez konularının; özet, anahtar kelimeler, bulgular ve sonuç bölümleri dikkate alınarak on altı ayrı grupta incelenmesi gerektiği düşünülmüştür. $\mathrm{Bu}$ gruplandırma yapılırken konu olarak (Tarım Ekonomisi /Kapitalizasyon Oranı veya Emlak Vergisi/E-Devlet/Avrupa Birliği gibi) birbirine yakın olanlar mümkün olduğunca bir grup altında toplanmaya çalışılmıştır. Buna rağmen ancak on altı ayrı gruba indirgenebilmiştir. $\mathrm{Bu}$ durum bize, taşınmaz değerleme konusunun, taşınmazlarla ilgili her alanda ihtiyaç duyulduğunu göstermektedir.

Tezlerde en çok incelenen konular sırasıyla 44 adet tez ile (\%34.92) Yöntemler/ Standartlar/Faktör Analizi, 27 adet tez ile $(\% 21.43)$ Genel Bilgi/Mevzuat/Değerleme Uzmanlığı, 22 adet tez ile (\%17.46) Sorunlar/ Çözüm Önerileri/Model Önerisi konularıdır. $\mathrm{Bu}$ alanda en çok incelenen konunun Yöntemler/Standartlar/Faktör Analizi olmasi, ülkemizdeki taşınmaz değerleme faaliyetlerinde kullanılan yöntem, uygulanan standartlar ve değere etki eden faktörlerin belirlenmesi konularında bazı eksiklikler olduğunu, yapılan çalışmaların da bu durumun giderilmesi adına bilimsel önerilerde bulunmak amacıyla yapıldığını göstermektedir. İkinci sırada Genel Bilgi/ Mevzuat/Değerleme Uzmanlığı konusunun inceleniyor olması, Türkiye değerleme sistemindeki mevcut durumu ortaya koymak ve değerleme uzmanlarının karşılaştıkları sorunlara çözüm önerileri getirmek amaçlıdır. Üçüncü sırada Sorunlar/Çözüm Önerileri/Model Önerisi konularının incelenmiş olması, değerleme sistemimizde yaşanan sorunların tespiti, yasal, kurumsal ve teknik çözüm önerileri geliştirilmesi, toplu ve tekil değerlemeler için model önerileri sunmak amaçlı çalışmalar yapıldığını göstermektedir (Tablo 4).

En az çalışma ise sırasıyla 1 adet tez ile (\%0.79) Arazi Politikası/Arazi Yönetimi, 2'şer adet tez ile (\%1.59) Sigorta Bedeli/ Hasar Oranı ve Yeşil Değerleme/ Enerji Etkin/Yeşil Bina konularında yapılmıştır. Tabloya göre bazı tezlerin birden çok konuyla ilgili olduğu görülmüştür. Buna göre, 67 adet tez bir konuyu, 53 adet tez iki konuyu, 5 adet tez üç konuyu ve 1 adet tez de dört konuyu araştırmıştır (Tablo 4). 
Tablo 4: Lisansüstü Tezlerin Çalışma Konularına Göre Dağılımı

\begin{tabular}{|c|c|c|c|c|c|c|c|c|c|c|c|c|c|c|c|c|c|}
\hline 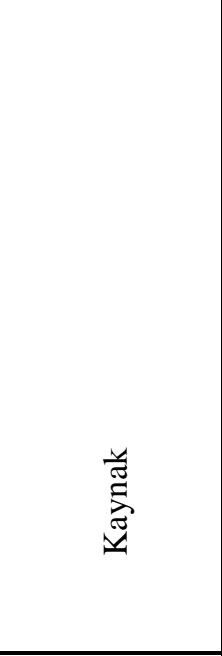 & 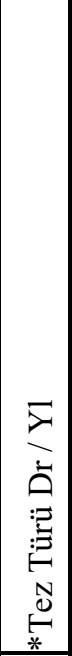 & 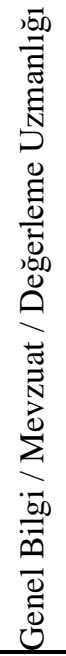 & 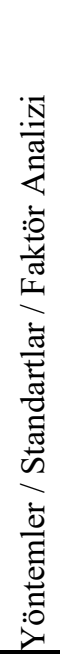 & 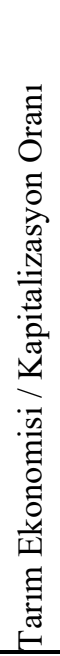 & 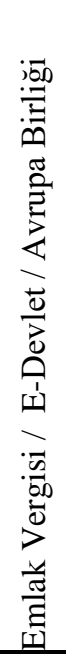 & 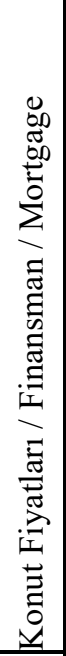 & 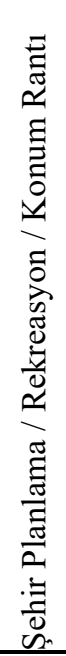 & 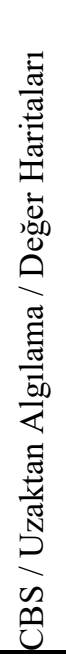 & 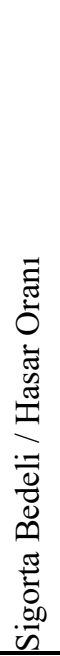 & 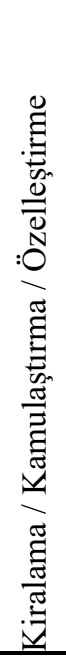 & 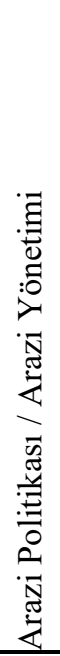 & 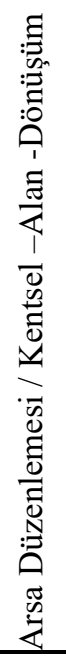 & 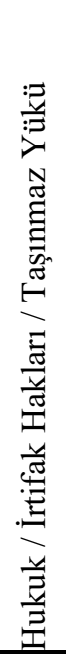 & 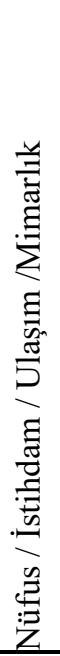 & 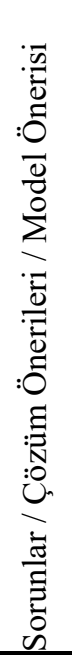 & 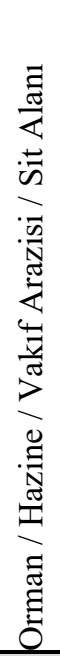 & 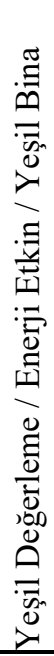 \\
\hline Aliefendioğlu, & Dr & & & & & & & & & & & & & & & & \\
\hline Bașdoğan, & $\mathrm{Dr}$ & & & & & & & & & & & & & & & & \\
\hline Bekiroğlu, & Dr & & & & & & & & & & & & & & & & \\
\hline Bostanc1, & $\mathrm{Dr}$ & & & & & & & & & & & & & & & & \\
\hline Boza, 2015 & $\mathrm{Dr}$ & & & & & & & & & & & & & & & & \\
\hline Cağatay, 2008 & $\mathrm{Dr}$ & & & & & & & & & & & & & & & & \\
\hline Cağdaş, 2007 & Dr & & & & & & & & & & & & & & & & \\
\hline Cete, 2008 & Dr & & & & & & & & & & & & & & & & \\
\hline Coruhlu, 2013 & $\mathrm{Dr}$ & & & & & & & & & & & & & & & & \\
\hline Erdem, 2016 & Dr & & & & & & & & & & & & & & & & \\
\hline Ertaș, 2000 & Dr & & & & & & & & & & & & & & & & \\
\hline Hacıköylü,20 & Dr & & & & & & & & & & & & & & & & \\
\hline Hepșen, 2010 & Dr & & & & & & & & & & & & & & & & \\
\hline Kabataș, 2005 & Dr & & & & & & & & & & & & & & & & \\
\hline Karakayacı, & Dr & & & & & & & & & & & & & & & & \\
\hline Nalbantoğlu, & Dr & & & & & & & & & & & & & & & & \\
\hline Nișanc1, 2005 & Dr & & & & & & & & & & & & & & & & \\
\hline Yalpir, 2007 & $\mathrm{Dr}$ & & & & & & & & & & & & & & & & \\
\hline (Nas) & $\mathrm{Y1}$ & & & & & & & & & & & & & & & & \\
\hline Akbas, 2010 & Y1 & & & & & & & & & & & & & & & & \\
\hline Akkaynak, & $\mathrm{Y1}$ & & & & & & & & & & & & & & & & \\
\hline Albulak, 2016 & $\mathrm{Y1}$ & & & & & & & & & & & & & & & & \\
\hline Amca, 2016 & Y1 & & & & & & & & & & & & & & & & \\
\hline Armut, 2016 & $\mathrm{Y1}$ & & & & & & & & & & & & & & & & \\
\hline Arslan, 2016 & $\mathrm{Y1}$ & & & & & & & & & & & & & & & & \\
\hline Asfuroğlu, & Y1 & & & & & & & & & & & & & & & & \\
\hline Atılgan, 2010 & Y1 & & & & & & & & & & & & & & & & \\
\hline Bahar, 2007 & $\mathrm{Y1}$ & & & & & & & & & & & & & & & & \\
\hline Baș, 2009 & Y1 & & & & & & & & & & & & & & & & \\
\hline Bașer, 2002 & $\mathrm{Y1}$ & & & & & & & & & & & & & & & & \\
\hline Baștürk, 2009 & $\mathrm{Y1}$ & & & & & & & & & & & & & & & & \\
\hline Bayram, 2010 & $\mathrm{Y1}$ & & & & & & & & & & & & & & & & \\
\hline Birinci,1993 & $\mathrm{Y1}$ & & & & & & & & & & & & & & & & \\
\hline Börekçi, 2014 & Y1 & & & & & & & & & & & & & & & & \\
\hline Bulut, 2011 & Y1 & & & & & & & & & & & & & & & & \\
\hline Büyükbaș, & $\mathrm{Y1}$ & & & & & & & & & & & & & & & & \\
\hline Candaș, 2012 & $\mathrm{Y1}$ & & & & & & & & & & & & & & & & \\
\hline Ceylan, 2007 & Y1 & & & & & & & & & & & & & & & & \\
\hline Çağdaș, 2001 & Y1 & & & & & & & & & & & & & & & & \\
\hline Cakır, 2013 & $\mathrm{Y1}$ & & & & & & & & & & & & & & & & \\
\hline Celik, 2015 & Y1 & & & & & & & & & & & & & & & & \\
\hline
\end{tabular}




\begin{tabular}{|c|c|c|c|c|c|c|c|c|c|c|c|c|c|c|c|c|c|}
\hline 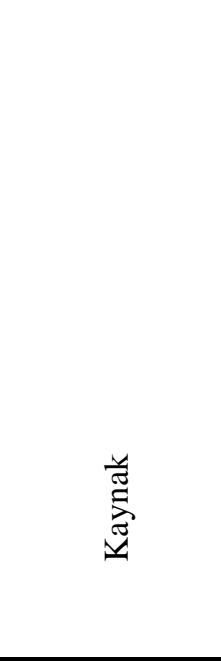 & 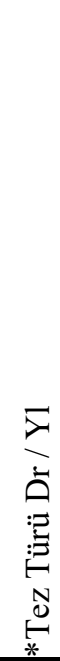 & 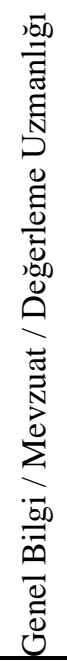 & 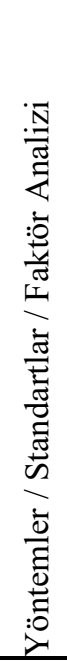 & 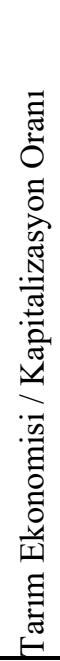 & 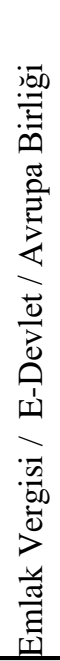 & 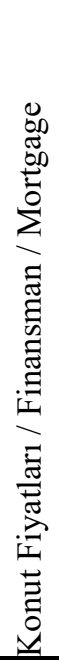 & 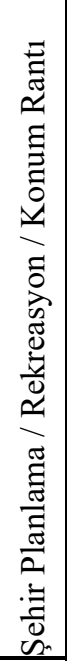 & 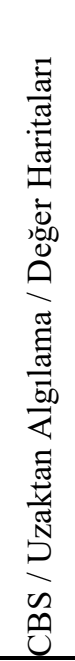 & 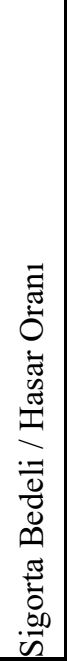 & 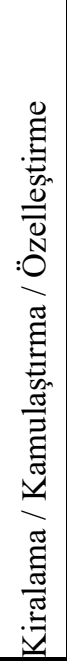 & 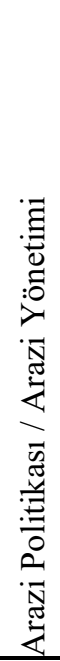 & 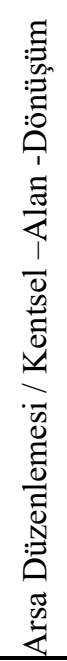 & 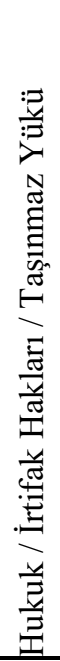 & 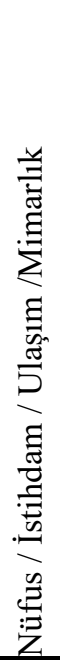 & 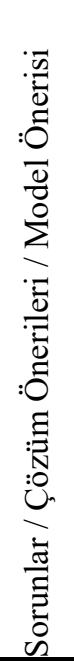 & 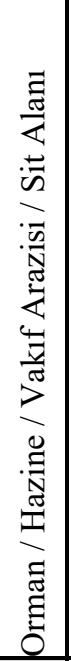 & 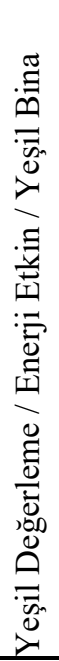 \\
\hline Cevik, 2012 & $\mathrm{Yl}$ & & & & & & & & & & & & & & & & \\
\hline Cinar, 2007 & $\mathrm{Yl}$ & & & & & & & & & & & & & & & & \\
\hline Dalkıran, & $\mathrm{Yl}$ & & & & & & & & & & & & & & & & \\
\hline Değirmenciler & $\mathrm{Yl}$ & & & & & & & & & & & & & & & & \\
\hline Derinpınar, & $\mathrm{Yl}$ & & & & & & & & & & & & & & & & \\
\hline Deveci, 2007 & $\mathrm{Yl}$ & & & & & & & & & & & & & & & & \\
\hline Doğrul, 2011 & $\mathrm{Y} 1$ & & & & & & & & & & & & & & & & \\
\hline Döner, 2010 & $\mathrm{Yl}$ & & & & & & & & & & & & & & & & \\
\hline Er, 2015 & $\mathrm{Y} 1$ & & & & & & & & & & & & & & & & \\
\hline Erdoğdu, & $\mathrm{Y} 1$ & & & & & & & & & & & & & & & & \\
\hline Erees, 2010 & $\mathrm{Yl}$ & & & & & & & & & & & & & & & & \\
\hline Eren, 1998 & Y1 & & & & & & & & & & & & & & & & \\
\hline Ergin, 2013 & $\mathrm{Yl}$ & & & & & & & & & & & & & & & & \\
\hline Ertas, 1992 & $\mathrm{Yl}$ & & & & & & & & & & & & & & & & \\
\hline Gemici, 2008 & $\mathrm{Yl}$ & & & & & & & & & & & & & & & & \\
\hline Gödur, 2016 & $\mathrm{Yl}$ & & & & & & & & & & & & & & & & \\
\hline Gölbaș1,2006 & $\mathrm{Yl}$ & & & & & & & & & & & & & & & & \\
\hline Gönülal, 2009 & $\mathrm{Yl}$ & & & & & & & & & & & & & & & & \\
\hline Gül, 1998 & $\mathrm{Yl}$ & & & & & & & & & & & & & & & & \\
\hline Güler, 2011 & $\mathrm{Yl}$ & & & & & & & & & & & & & & & & \\
\hline Gündoğdu, & $\mathrm{Yl}$ & & & & & & & & & & & & & & & & \\
\hline Hasanova, & $\mathrm{Yl}$ & & & & & & & & & & & & & & & & \\
\hline Hayta, 2007 & $\mathrm{Y} 1$ & & & & & & & & & & & & & & & & \\
\hline Hurma, 2000 & $\mathrm{Yl}$ & & & & & & & & & & & & & & & & \\
\hline İlyasoğlu, & $\mathrm{Yl}$ & & & & & & & & & & & & & & & & \\
\hline Kabatas 2010 & $\mathrm{Yl}$ & & & & & & & & & & & & & & & & \\
\hline Karabaș, 2010 & $\mathrm{Yl}$ & & & & & & & & & & & & & & & & \\
\hline Karaca, 2008 & $\mathrm{Yl}$ & & & & & & & & & & & & & & & & \\
\hline Karagöl, 2009 & $\mathrm{Yl}$ & & & & & & & & & & & & & & & & \\
\hline Karakuș, & $\mathrm{Yl}$ & & & & & & & & & & & & & & & & \\
\hline Karatas, 2011 & $\mathrm{Yl}$ & & & & & & & & & & & & & & & & \\
\hline Karayünlü, & $\mathrm{Yl}$ & & & & & & & & & & & & & & & & \\
\hline Kaya, 2011 & $\mathrm{Yl}$ & & & & & & & & & & & & & & & & \\
\hline Kaynar, 2014 & $\mathrm{Yl}$ & & & & & & & & & & & & & & & & \\
\hline Kepçeli, 1990 & $\mathrm{Yl}$ & & & & & & & & & & & & & & & & \\
\hline Keskin, 2007 & $\mathrm{Yl}$ & & & & & & & & & & & & & & & & \\
\hline Keykubat, & $\mathrm{Yl}$ & & & & & & & & & & & & & & & & \\
\hline Kurar, 2008 & $\mathrm{Y} 1$ & & & & & & & & & & & & & & & & \\
\hline Köse, 2001 & $\mathrm{Yl}$ & & & & & & & & & & & & & & & & \\
\hline Kül, 2009 & $\mathrm{Yl}$ & & & & & & & & & & & & & & & & \\
\hline Kurt, 2004 & $\mathrm{Yl}$ & & & & & & & & & & & & & & & & \\
\hline Küçükdoğan, & $\mathrm{Yl}$ & & & & & & & & & & & & & & & & \\
\hline Leylek, 1993 & $\mathrm{Yl}$ & & & & & & & & & & & & & & & & \\
\hline
\end{tabular}




\begin{tabular}{|c|c|c|c|c|c|c|c|c|c|c|c|c|c|c|c|c|c|}
\hline 駡 & 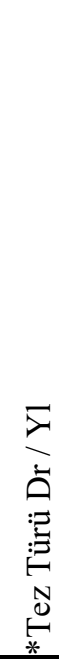 & 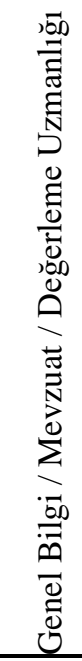 & 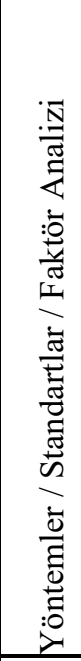 & 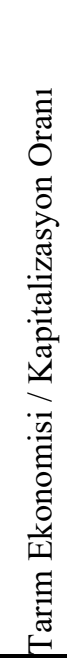 & 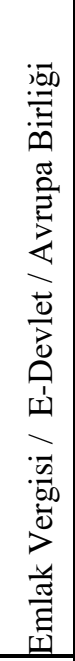 & 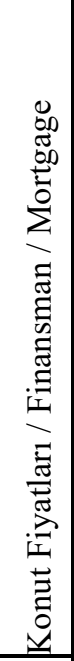 & 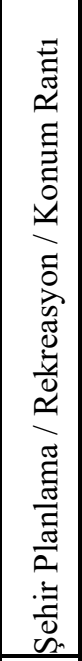 & 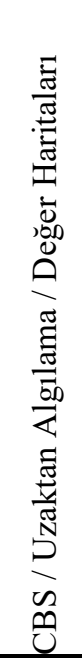 & 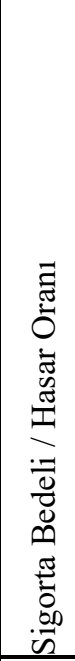 & 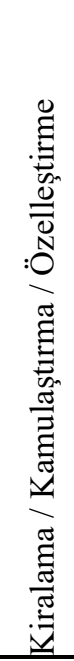 & 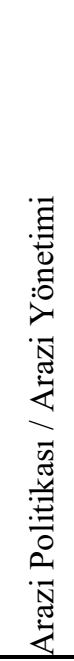 & 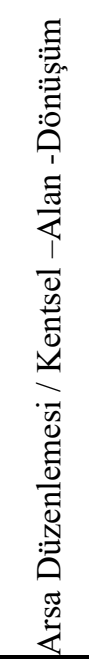 & 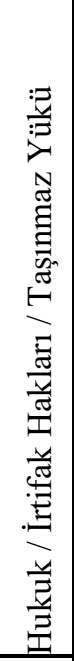 & 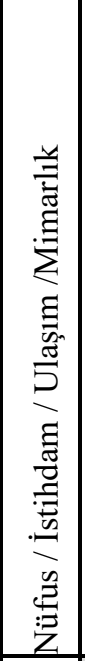 & 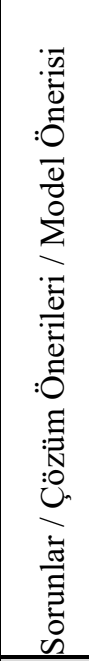 & 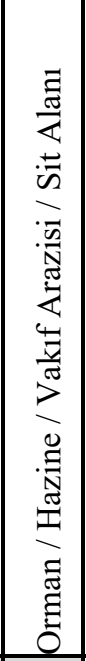 & 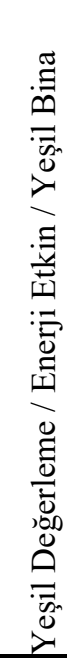 \\
\hline Lüküslü, 2006 & $\mathrm{Yl}$ & & & & & & & & & & & & & & & & \\
\hline Narin, 2010 & $\mathrm{Yl}$ & & & & & & & & & & & & & & & & \\
\hline Nikes, 2005 & $\mathrm{Yl}$ & & & & & & & & & & & & & & & & \\
\hline Nuhoğlu, & $\mathrm{Yl}$ & & & & & & & & & & & & & & & & \\
\hline Oğuz, 2011 & $\mathrm{Yl}$ & & & & & & & & & & & & & & & & \\
\hline Özbay, 2010 & $\mathrm{Yl}$ & & & & & & & & & & & & & & & & \\
\hline Özçelik, 2004 & $\mathrm{Yl}$ & & & & & & & & & & & & & & & & \\
\hline Özer, 2010 & $\mathrm{Yl}$ & & & & & & & & & & & & & & & & \\
\hline Özfidan, 2008 & $\mathrm{Yl}$ & & & & & & & & & & & & & & & & \\
\hline Özkan, 2009 & $\mathrm{Yl}$ & & & & & & & & & & & & & & & & \\
\hline Özpak, 2006 & $\mathrm{Yl}$ & & & & & & & & & & & & & & & & \\
\hline Pehlivan, & $\mathrm{Yl}$ & & & & & & & & & & & & & & & & \\
\hline Saçın, 2009 & $\mathrm{Yl}$ & & & & & & & & & & & & & & & & \\
\hline Sağında, 2001 & $\mathrm{Yl}$ & & & & & & & & & & & & & & & & \\
\hline Sarac, 2012 & $\mathrm{Yl}$ & & & & & & & & & & & & & & & & \\
\hline Savașir, 2013 & $\mathrm{Yl}$ & & & & & & & & & & & & & & & & \\
\hline Savuran, 2008 & $\mathrm{Yl}$ & & & & & & & & & & & & & & & & \\
\hline Sezer, 2010 & $\mathrm{Yl}$ & & & & & & & & & & & & & & & & \\
\hline Sezgin, 2010 & $\mathrm{Yl}$ & & & & & & & & & & & & & & & & \\
\hline Sahin, 2010 & $\mathrm{Yl}$ & & & & & & & & & & & & & & & & \\
\hline Tanrivermiș, & $\mathrm{Yl}$ & & & & & & & & & & & & & & & & \\
\hline Tatoğlu, 2008 & $\mathrm{Yl}$ & & & & & & & & & & & & & & & & \\
\hline Timur, 2009 & $\mathrm{Yl}$ & & & & & & & & & & & & & & & & \\
\hline Torun, 2009 & $\mathrm{Yl}$ & & & & & & & & & & & & & & & & \\
\hline Tunçer, 2014 & $\mathrm{Yl}$ & & & & & & & & & & & & & & & & \\
\hline Türeoğlu, & $\mathrm{Yl}$ & & & & & & & & & & & & & & & & \\
\hline Ucar, 2009 & $\mathrm{Yl}$ & & & & & & & & & & & & & & & & \\
\hline Ustaoğlu, & $\mathrm{Yl}$ & & & & & & & & & & & & & & & & \\
\hline Utkucu, 2007 & $\mathrm{Yl}$ & & & & & & & & & & & & & & & & \\
\hline Uzer, 2009 & $\mathrm{Yl}$ & & & & & & & & & & & & & & & & \\
\hline Uzer, 2010 & $\mathrm{Yl}$ & & & & & & & & & & & & & & & & \\
\hline Ünlü, 2010 & $\mathrm{Yl}$ & & & & & & & & & & & & & & & & \\
\hline Ünsal, 2011 & Y1 & & & & & & & & & & & & & & & & \\
\hline Üreten, 2007 & $\mathrm{Yl}$ & & & & & & & & & & & & & & & & \\
\hline Üstün, 2009 & $\mathrm{Y} 1$ & & & & & & & & & & & & & & & & \\
\hline Yahși, 2007 & $\mathrm{Yl}$ & & & & & & & & & & & & & & & & \\
\hline Yalçın, 2006 & $\mathrm{Yl}$ & & & & & & & & & & & & & & & & \\
\hline Yalpir, 2000 & $\mathrm{Yl}$ & & & & & & & & & & & & & & & & \\
\hline Yildırım, & $\mathrm{Yl}$ & & & & & & & & & & & & & & & & \\
\hline Y1ld1z, 2014 & $\mathrm{Yl}$ & & & & & & & & & & & & & & & & \\
\hline Y1lmaz, 2010 & $\mathrm{Yl}$ & & & & & & & & & & & & & & & & \\
\hline Yedievli, & $\mathrm{Yl}$ & & & & & & & & & & & & & & & & \\
\hline Toplam & 12 & 27 & 44 & 9 & 7 & 12 & 6 & 16 & 2 & 11 & 1 & 15 & 1 & 4 & 22 & 8 & 2 \\
\hline
\end{tabular}




\begin{tabular}{|c|c|c|c|c|c|c|c|c|c|c|c|c|c|c|c|c|c|}
\hline 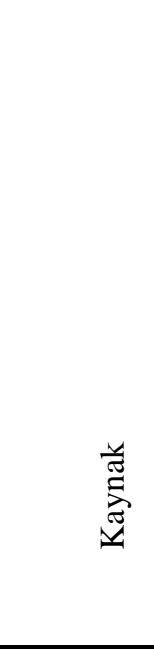 & 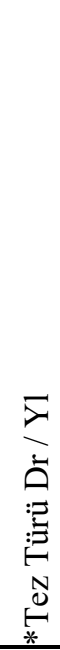 & 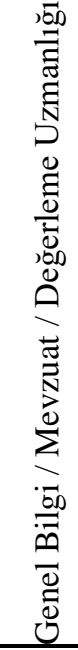 & 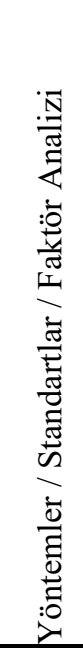 & 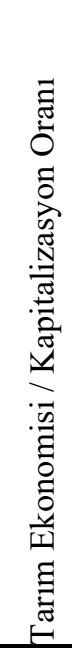 & 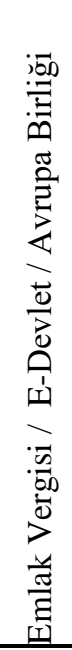 & 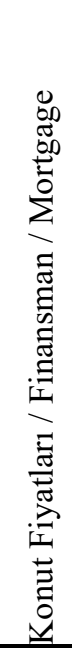 & 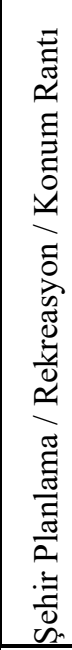 & 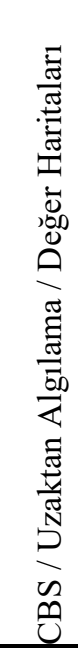 & 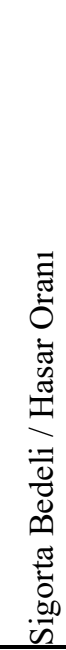 & 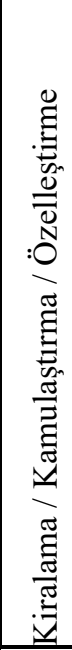 & 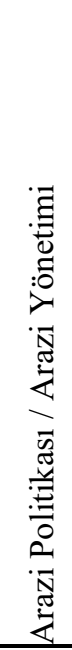 & 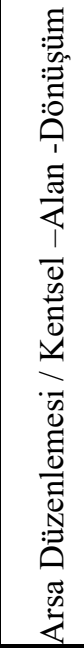 & 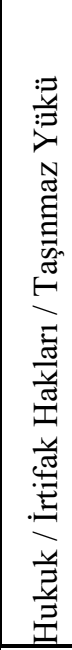 & 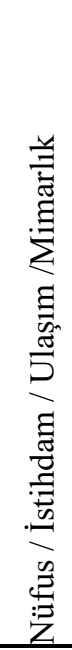 & 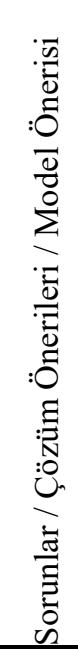 & 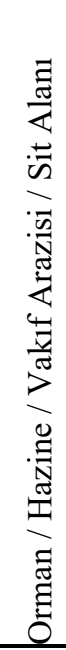 & 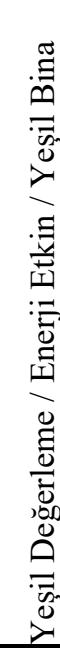 \\
\hline Oran (\%) & 10 & 21.4 & 34.9 & 7.1 & 5.5 & 9.5 & 4.7 & 12.7 & 1.5 & 8.7 & 0.7 & 11.9 & 5.5 & 3.1 & 17.4 & 6.3 & 1.5 \\
\hline
\end{tabular}

*Çalışmada doktora tezleri için Dr, yüksek lisans tezleri için Yl ifadesi kullanılmıştır.

Tezlerdeki incelenen konularının yillara göre dağılımına bakıldığında, 2006-2010 yılları arasında ilgili tez sayılarında büyük bir artış olduğu görülmektedir (Tablo 5). Bunun, Amerika Birleşik Devletleri'nde 2008 yilındaki mortgage krizinden kaynaklandığı söylenebilir. En az gündeme gelen konulardan birisi olan Yeşil Değerleme /Enerji Etkin/Yeşil Bina konusunun da son yıllarda gündeme gelmeye başladığı, tüm dünyada çevre koruma ve enerji tasarrufu konusundaki duyarlılığın artmasıyla birlikte bu alandaki çalışmaların da önem kazanacağı düşünülmektedir.

Tablo 5: Lisansüstü Tezlerindeki Konuların Yıllara Göre Dağılımı.

\begin{tabular}{|c|c|c|c|c|c|c|c|c|c|c|c|c|c|c|c|c|}
\hline & 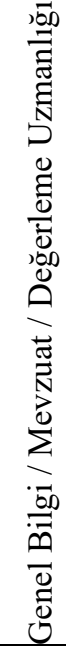 & 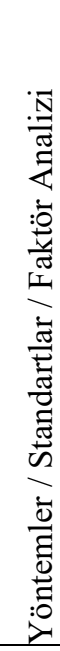 & 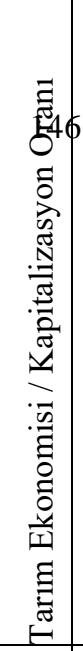 & 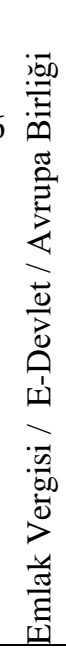 & 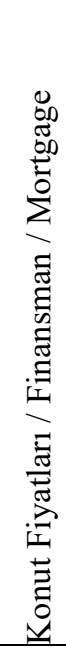 & 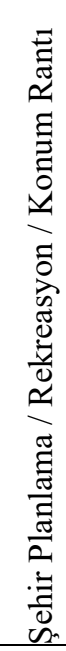 & 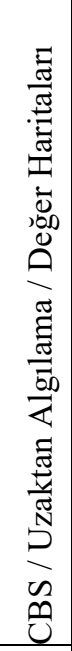 & 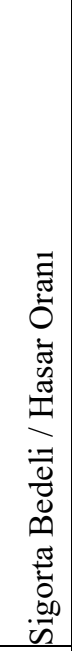 & 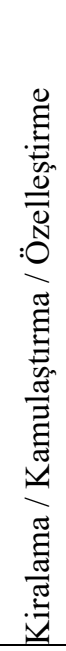 & 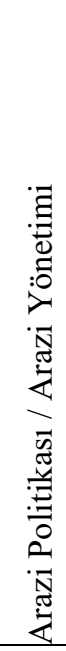 & 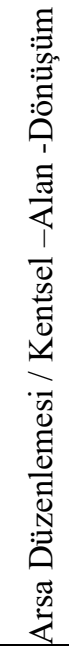 & 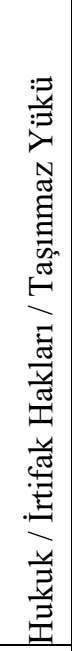 & 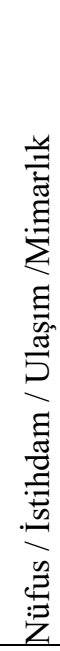 & 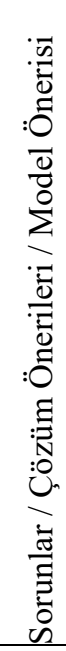 & 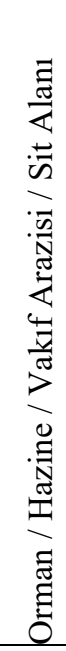 & 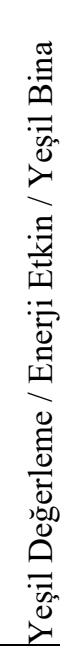 \\
\hline $1990-1995$ & & 1 & 3 & & & & & 1 & 1 & & 1 & & & & & \\
\hline $1996-2000$ & 2 & 2 & 1 & & & 1 & 1 & & 1 & & 1 & & & 2 & 1 & \\
\hline 2001-2005 & 5 & 3 & 2 & 1 & 1 & 1 & 1 & 1 & & & 2 & & 1 & 3 & & \\
\hline 2006-2010 & 12 & 19 & 1 & 3 & 6 & 3 & 8 & & 6 & 1 & 6 & 4 & 2 & 10 & 4 & 1 \\
\hline 2011-2015 & 5 & 17 & 2 & 3 & 4 & & 5 & & 3 & & 2 & 3 & 1 & 6 & 3 & 1 \\
\hline 2016-2020 & 3 & 2 & & & 1 & 1 & 1 & & & & 3 & & & 1 & & \\
\hline Toplam & 27 & 44 & 9 & 7 & 12 & 6 & 16 & 2 & 11 & 1 & 15 & 7 & 4 & 22 & 8 & 2 \\
\hline
\end{tabular}

Araştırma kapsamında incelenen tezlerin, ilgili üniversite ve yıllara göre dağılımı Tablo 6'da verilmiştir. Tabloya göre en fazla yayın $1(\% 5.55)$ doktora ve 23 (\%21.3) yüksek lisans tezi ile İTÜ'de yapılmıştır. Yıllar bazında bakıldığında ise, 8 doktora ve 53 yüksek lisans tezi olmak üzere toplamda 61 
yayın ile 2006-2010 yılları arasında yoğun bir çalışma yapıldı̆̆ı görülmektedir (Şekil 1).

Tablo 6: Üniversitelerin Lisansüstü Tez Sayısı ve Yayınlama Yılına Göre Dağılım.
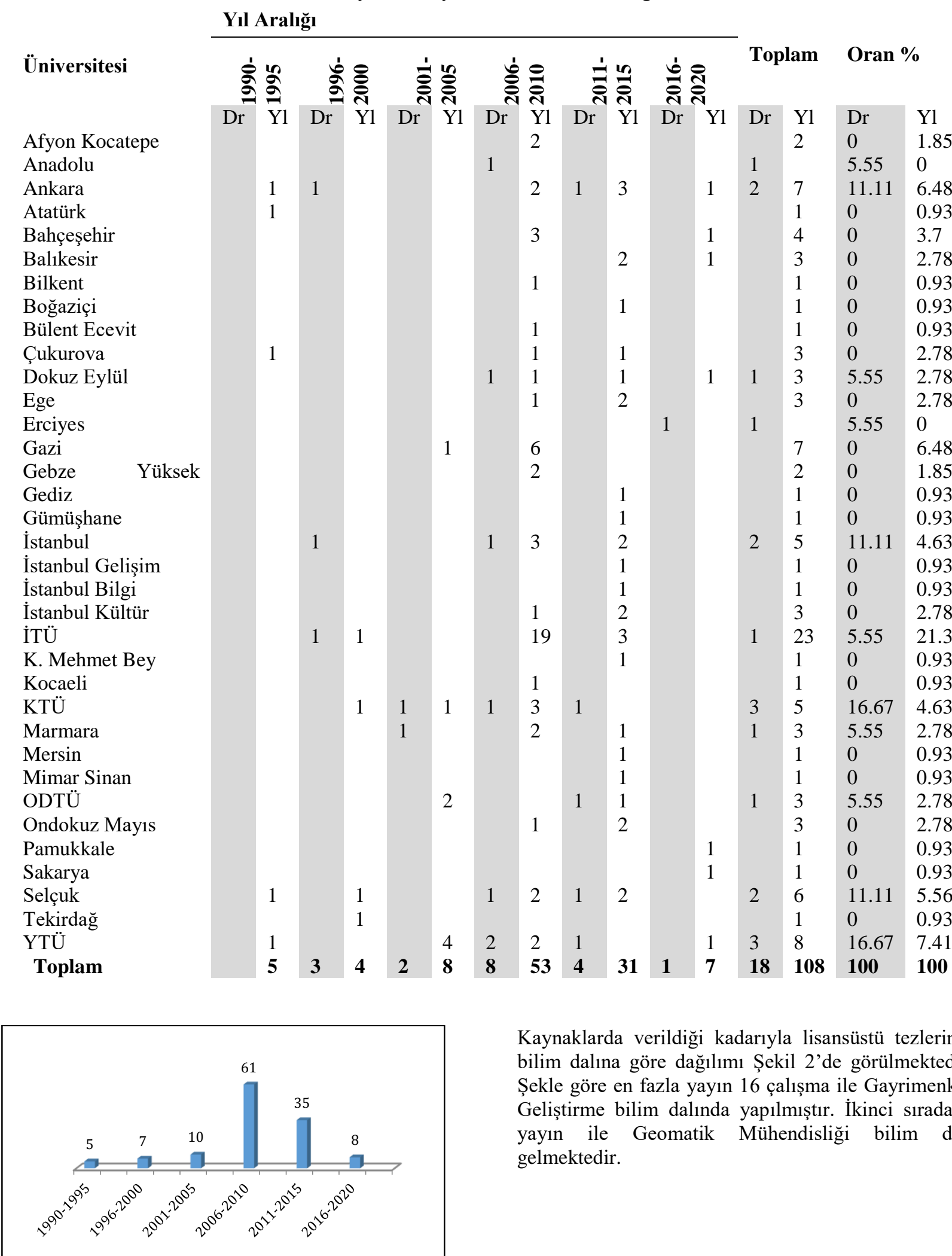

Kaynaklarda verildiği kadarıyla lisansüstü tezlerinin bilim dalına göre dağılımı Şekil 2'de görülmektedir. Şekle göre en fazla yayın 16 çalışma ile Gayrimenkul Geliştirme bilim dalında yapılmıştır. İkinci sırada 6 yayın ile Geomatik Mühendisliği bilim dalı gelmektedir.

Şekil 1: Lisansüstü Tezlerin Yayınlanma Yıl Aralığına Göre Dağılımı. 


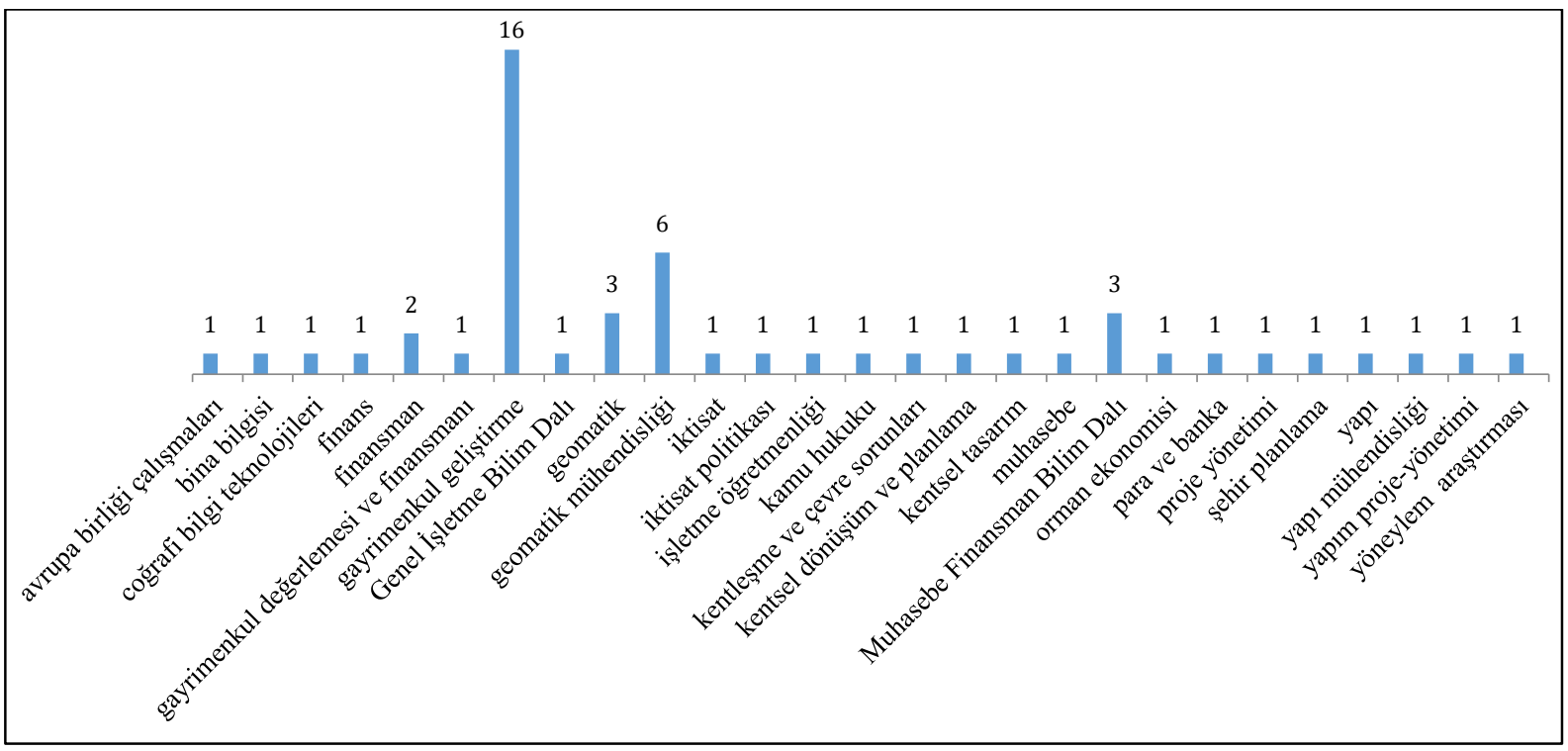

Şekil 2: Lisansüstü Tezlerinin Bilim Dalına Göre Dağılımı.

Tezlerin yayın diline göre dağılımı incelendiğinde, 117 tez ile Türkçe (\%92.857) ve 9 tez ile İngilizce (\%7.142) hazırlanmış olduğu görülmektedir (Tablo 7). 
Tablo 7: Tezlerinin Yayın Diline Göre Dağılımı.

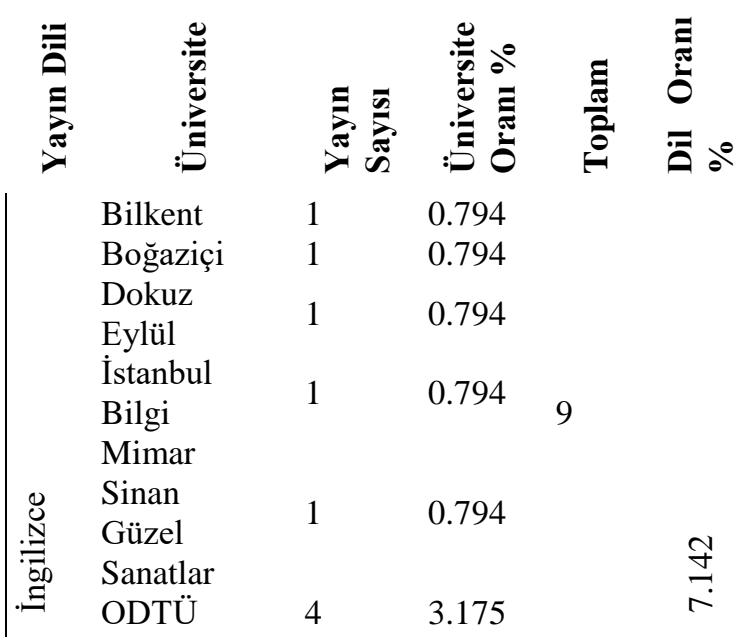

Afyon

Kocatepe $\quad 2 \quad 1.587$

$\begin{array}{lll}\text { Anadolu } & 1 & 0.794\end{array}$

$\begin{array}{lll}\text { Ankara } & 9 & 7.143\end{array}$

Atatürk $\quad 1 \quad 0.794$

Bahçeşehir $4 \quad 3.175$

Balıkesir $\quad 3 \quad 2.381$

$\begin{array}{lll}\text { Bülent } & 1 & 0.794\end{array}$

Çukurova $\quad 3 \quad 2.381$

$\begin{array}{lll}\text { Dokuz } & 3 & 2.381\end{array}$

$\begin{array}{lll}\text { Eylül } & 3 & 2.381\end{array}$

$\begin{array}{lll}\text { Erciyes } & 1 & 0.794\end{array}$

$\begin{array}{lll}\text { Gazi } & 7 & 5.556\end{array}$

Gebze

$\begin{array}{lll}\text { Yüksek } & 2 & 1.587\end{array}$

Enst.

Gediz $\quad 1 \quad 0.794$

Gümüşhane $1 \quad 0.794 \quad 117$

$\begin{array}{lll}\text { İstanbul } & 1 & 0.794\end{array}$

Gelişim 1

İstanbul $\quad 3 \quad 2.381$

$\begin{array}{lll}\text { Kültür } & 3 & \\ \text { İTÜ } & 24 & 19.05\end{array}$

İstanbul $7 \quad 5.556$

$\begin{array}{lll}\text { KTÜ } & 8 & 6.349\end{array}$

K. Mehmet $1 \quad 0.794$

Bey

$\begin{array}{lll}\text { Kocaeli } & 1 & 0.794 \\ & & 3.175\end{array}$

Marmara $\quad 4 \quad 3.175$

Mersin 110.794

$\begin{array}{lll}\text { Ondokuz } & 3 & 2.381\end{array}$

$\begin{array}{lll}\text { Mayıs } & 3 & 2.381 \\ \text { Pamukkale } & 1 & 0.794\end{array}$

Sakarya $\quad 1 \quad 0.794$

$\begin{array}{lll}\text { Selçuk } & 8 & 6.349\end{array}$

$\begin{array}{lll}\text { Tekirdağ } & 1 & 0.794\end{array}$

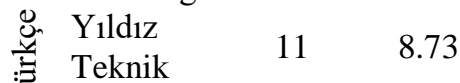

$\begin{array}{lllll}\text { Toplam } & 126 & 100 & 126 & 100\end{array}$ 
Araştırma kapsamında incelenen tezlerin sayfa sayısına göre dağılımı incelenmiş (Tablo 8) ve doktora tezlerinin ortalama sayfa sayısının 288, yüksek lisans tezlerinin ise 143 olduğu görülmüştür. Doktora tezlerin yaklaşık yarısı (8 adet ile \%44.444) 201-250, yüksek lisans tezlerinin ise yine yaklaşı yarısı (44 adet ile \%40.471) 101150 sayfa aralığındadır.

Tablo 8: Tezlerin Sayfa Sayısına Göre Dağılımı.

\begin{tabular}{|c|c|c|c|c|c|}
\hline 包 & 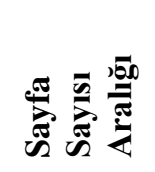 & : & $\hat{\theta}^{0}$ & 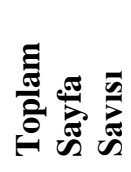 & 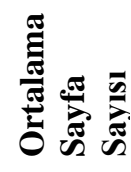 \\
\hline \multirow{6}{*}{ Doktora } & $140-200$ & 2 & 11.111 & 331 & 165.5 \\
\hline & $201-250$ & 8 & 44.444 & 1840 & 230 \\
\hline & $251-300$ & 1 & 5.5556 & 289 & 289 \\
\hline & $301-350$ & 6 & 33.333 & 1953 & 325.5 \\
\hline & $351-\ldots$ & 1 & 5.5556 & 774 & 774 \\
\hline & Toplam & 18 & 100 & 5187 & 288.17 \\
\hline \multirow{7}{*}{$\begin{array}{l}\text { Yüksek } \\
\text { Lisans }\end{array}$} & $50-100$ & 26 & 24.074 & 2138 & 82.231 \\
\hline & $101-150$ & 44 & 40.741 & 5348 & 121.55 \\
\hline & $151-200$ & 21 & 19.444 & 3742 & 178.19 \\
\hline & $201-250$ & 15 & 13.889 & 2905 & 223.46 \\
\hline & $251-300$ & 1 & 0.9259 & 565 & 282.5 \\
\hline & $301-\ldots$ & 1 & 0.9259 & 836 & 418 \\
\hline & Toplam & 108 & 100 & 15534 & 143.83 \\
\hline \multicolumn{2}{|c|}{ Genel Toplam } & 126 & 100 & 20721 & 164.45 \\
\hline
\end{tabular}

Tezlerde danışmanlık yapan öğretim üyelerinin unvan dağılımı da incelenmiştir. Buna göre; doktora tezlerinde 11 tez ile (\%61) profesör doktor ve 5 tez ile (\%28) doçent doktor, yüksek lisans tezlerin de ise 46 tez ile ( $\% 43)$ profesör doktor, 25 tez ile $(\% 23)$ doçent doktor ve 30 tez ile (\%28) yardımcı doçent doktor unvanını taşıyan öğretim üyelerinin danışmanlık yaptığı görülmektedir. Ayrıca yüksek lisans tezlerinde az da olsa 7 tez ile (\%6) doktor unvanlı öğretim elemanlarının da danışmanlık yaptığı belirlenmiştir.

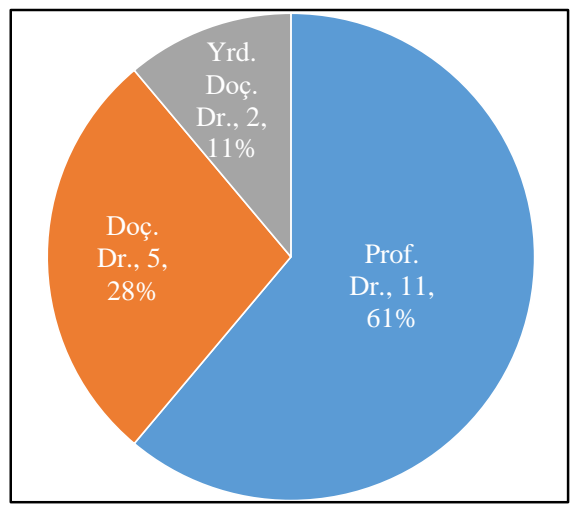

Şekil 3: Doktora Çalışmalarının Danışman Unvanına Göre Dağılımı. 


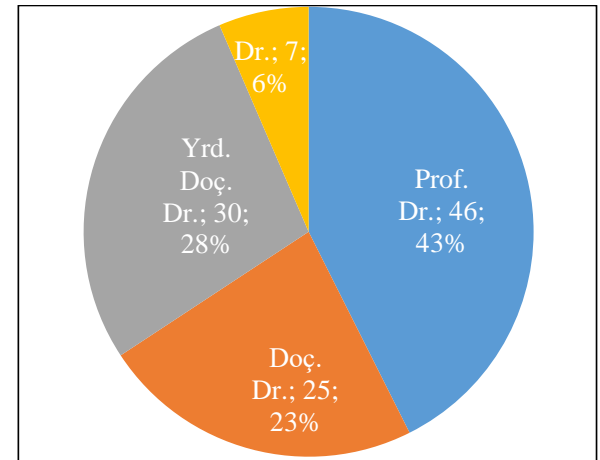

Şekil 4: Yüksek Lisans Çalışmalarının Danışman Unvanına Göre Dağılımı

Konuyla ilgili lisansüstü tezleri hazırlayan araştırmacıların, çalıştıkları üniversiteler Tablo 9'da verilmiştir. Buna göre, üniversitelerde görev yapan

Tablo 9: Araştırmacıların Çalıștıkları Üniversitelerin Dağılımı

\begin{tabular}{|l|l|l|}
\hline Üniversitesi & Sayısi & $\begin{array}{l}\text { Oranı } \\
\text { \% }\end{array}$ \\
\hline Afyon Kocatepe & 1 & 1.01 \\
\hline Anadolu & 1 & 1.01 \\
\hline Ankara & 7 & 7.071 \\
\hline Atatürk & 1 & 1.01 \\
\hline Bahçeşehir & 2 & 2.02 \\
\hline Balıkesir & 1 & 1.01 \\
\hline Boğaziçi & 1 & 1.01 \\
\hline Bülent Ecevit & 1 & 1.01 \\
\hline Çukurova & 3 & 3.03 \\
\hline Dokuz Eylül & 4 & 4.04 \\
\hline Ege & 3 & 3.03 \\
\hline Erciyes & 1 & 1.01 \\
\hline Gazi & 6 & 6.061 \\
\hline Gebze İleri Teknoloji Enstitüsü & 2 & 2.02 \\
\hline Gediz & 1 & 1.01 \\
\hline Gümüşhane & 1 & 1.01 \\
\hline İstanbul & 7 & 7.071 \\
\hline İstanbul Bilgi & 1 & 1.01 \\
\hline İstanbul Kültür & 3 & 3.03 \\
\hline İTÜ & 19 & 19.19 \\
\hline Karamanoğlu Mehmet Bey & 1 & 1.01 \\
\hline Kocaeli & 1 & 1.01 \\
\hline KTÜ & 8 & 8.081 \\
\hline Marmara & 3 & 3.03 \\
\hline Mimar Sinan & 1 & 1.01 \\
\hline ODTÜ & 3 & 3.03 \\
\hline Ondokuz Mayıs & 1 & 1.01 \\
\hline Selçuk & 7 & 7.071 \\
\hline Tekirdă̆ & 1 & 1.01 \\
\hline YTÜ & 7 & 7.071 \\
\hline Toplam & 99 & 100 \\
\hline & & \\
\hline & & \\
\hline & 1 & \\
\hline
\end{tabular}

\section{SONUÇ VE ÖNERILER}

$\mathrm{Bu}$ çalışmada Yükseköğrenim Kurulu Ulusal Tez Merkezi veri tabanında bulunan "taşınmaz/gayrimenkul değerleme" anahtar sözcükleri altında kayıtlı olan tezler incelenmiştir. araștırmacıların 19'u (\%19.19) İTÜ'de görevli iken, $8(\% 8.081)$ araştırmacı KTÜ'de görev yapmaktadır (Tablo 9).

Taşınmazlar dünyasındaki hızlı gelişmelere paralel olarak, taşınmaz değerleme alanında yapılan akademik çalışmalar da artmaktadır. Çalışma kapsamında 1990-2017 yılları arasında Türkiye'de bu alanda yapılan toplam 126 adet (108 yüksek lisans, 18 doktora) akademik çalışma incelenmiştir. Üretilen tezler incelendiğinde;

- Ülkemizde taşınmaz değerleme alanında incelenen lisansüstü tezlerin üniversite ve ilgili anabilim dalına göre dağılımına bakıldığında, 35 farklı Devlet veya Vakıf üniversitesinin 38 farklı anabilim dalında taşınmaz değerleme alanında lisansüstü tezleri kabul edilmiştir. En fazla çalışma 13 adet (\%12) yüksek lisans tez çalışması ile İTÜ Disiplinler Arası Anabilim dalında yapılmıştır.

- Taşınmaz değerleme alanı, taşınmazların artan öneminden dolayı değişik disiplinlerin çalışma konusu olmuştur. Bunun bir sonucu olarak, ülkemizdeki taşınmazlar dünyasıyla ilgili akademisyenlerin pek çoğu taşınmaz değerleme alanında çalışma yapmayı tercih etmiştir.

- Çalışma kapsamında incelenen lisansüstü tezlerindeki araştırılan konuların dağılımına bakıldığında, bazı tezlerin birden fazla konuyla ilgili olduğu ve en fazla incelenen konuların sirasiyla Yöntemler/Standartlar /Faktör Analizi, Sorunlar/Çözüm Önerileri/Model Önerisi ve Genel Bilgi/Mevzuat/Değerleme Uzmanlığı alanları olduğu görülmüştür.

- Hazırlanan tezlerin yillar bazındaki dağılımına bakıldığında ise, 8 doktora ve 53 yüksek lisans tezi olmak üzere toplamda 61 yayın ile 2006-2010 y1lları arasında yoğun bir çalışma yapıldığı görülmektedir. Buradaki en önemli etkenin 2008 yılında Amerika Birleşik Devletlerinde meydana gelen mortgage 
krizi olduğu ve akademisyenlerin bu alana olan ilgisini arttırdığı söylenebilir.

- Şu an ülkemizde sadece bir üniversitede değerleme alanında lisans derecesinde eğitim verilmektedir. Değerleme mesleğinin sosyal ve ekonomik yönden ülkemiz adına taşıdığı önem dikkate alındığında, üniversitelerin taşınmazlar dünyasıyla ilgili (inşaat, ziraat, harita mühendisliği ve mimarlık) bölümlerinde değerlemeyle ilgili derslerin verilmesi büyük önem arz etmektedir.

- Taşınmaz değerlemesi faaliyetlerinin bütüncül bir kurumsal yapılanma çerçevesinde ve uzmanlar marifetiyle gerçekleştirilmesi önerilmektedir. Değerleme işlemleri, bu alanda altyapıya sahip olan, başta Harita Mühendisliği olmak üzere, İnşaat Mühendisliği, Şehir ve Bölge Planlama, Mimarlık ve Ziraat Mühendisliği gibi taşınmazlar dünyasıyla ilgili meslek disiplinlerinde çalışan elemanlar tarafından gerçekleştirilmelidir. Değerlemenin en önemli verileri arasında yer alan mekânsal bilgileri üreten ve yöneten bir meslek dalı olan Harita Mühendisliği, değerleme çalışmalarını organize eden ve yöneten lider disiplin rolünü üstlenmelidir.

\section{KAYNAKLAR}

[1] FIG Policy Statement. The FIG Statement on the Cadastre. Publication No. 11, Copenhagen, Denmark, 1995.

[2] Türk Dil Kurumu. "Güncel Türkçe Sözlük". http://www.tdk.gov.tr (10.12. 2015).

[3] Sermaye Piyasası Kurumu. "Sermaye Piyasasında Uluslararası Değerleme Standartları Hakkında Tebliğ Eki". Seri: VIII, No: 45, http://www.spk.gov.tr (23.12. 2015).

[4] Candaş E. Taşınmaz Değerlemesi İçin Mevzuat Altyapısının Modellenmesi. Yüksek Lisans Tezi, İstanbul Teknik Üniversitesi, Fen Bilimleri Enstitüsü, İstanbul, Türkiye, 2012.

[5] HKMO Sempozyum Bildiriler Kitabı. Arazi Yönetiminde Taşınmaz Değerleme ve Kadastro Sempozyumu, ATO Uluslararası Kongre ve Sergi
Saray1, HKMO\&TKGM, 22-23 Mayı, Ankara, 2012.

[6] Açlar A, Çağdaş V. Taşınmaz (Gayrimenkul) Değerlemesi. HKMO, ISBN 975395-551-0, Ankara, Türkiye, 2008.

[7] Yalpır Ş. Bulanık Mantık Metodolojisi İle Taşınmaz Değerleme Modelinin Geliştirilmesi ve Uygulaması: Konya Örneği. Doktora Tezi, Selçuk Üniversitesi, Fen Bilimleri Enstitüsü, Konya, Türkiye, 2007.

[8] Çete M. Türkiye İçin Bir Arazi İdare Sistemi Yaklaşımı. Doktora Tezi, Karadeniz Teknik Üniversitesi, Fen Bilimleri Enstitüsü, Trabzon, Türkiye, 2008.

[9] Köktürk E, Köktürk E. Taşınmaz Değerlemesi, Taşınmaz Hukuku - İmar Hukuku Değerleme Yöntemleri, Seçkin Yayıncılık, 2. Bask1, Ankara, 2015.

[10] Alkan G. "Türkiye'de muhasebe alanında yapılan lisansüstü tez çalışmaları üzerine bir araştırma (1984-2012)". Muhasebe ve Finansman Dergisi, Ocak, 2014.

[11] Çiçek D, Kozak N. "Anatolia: Turizm Araştırmaları Dergisi'nde yayımlanan hakem denetimli makalelerin bibliyometrik profili". Türk Kütüphaneciliği, 26 (4), 734-756, 2012.

[12] Kozak N. "Türkiye' de akademik turizm literatürünün gelişim süreci üzerine bir inceleme, Doğu Akdeniz Üniversitesi”. Turizm Araştırmaları Dergisi, 1(1), 15-55, 2000.

[13] Turan S, Karadağ E, Bektaş F, Yalçın M. "Türkiye'de eğitim yönetiminde bilgi üretimi: Kuram ve Uygulamada Eğitim Yönetimi Dergisi 2003-2013 yayınlarının incelenmesi". Kuram ve Uygulamada Eğitim Yönetimi, 20(1), 93-119, 2014. [14] Boztoprak T, Demir O, Çoruhlu YE. "Türkiye'de harita/geomatik mühendisliğinde yapılan doktora tezlerinin içerik analizi". Yükseköğretim ve Bilim Dergisi, 6(2), 252-260, 2016.

[15] Bauer MW, Gaskell G. Qualitative Researching with Text, Image and Sound London. Sage Publication Ltd., London, England, 2003.

[16] Boztoprak T, Demir O, Çoruhlu, Y E. "Türkiye'de arazi toplulaştırması üzerine yapılmış akademik çalışmaların analizi”. KSÜ Doğa Bilimleri Dergisi, 18(4), 2015. 